\title{
Analysis of histology and long noncoding RNAs involved in the rabbit hair follicle density using RNA sequencing
}

\author{
Haisheng Ding, Huiling Zhao, Xiaowei Zhao, Yunxia Qi, Xiaofei Wang and Dongwei Huang*
}

\begin{abstract}
Background: Hair follicle density influences wool fibre production, which is one of the most important traits of the Wan Strain Angora rabbit. However, molecular mechanisms regulating hair follicle density have remained elusive.

Results: In this study, hair follicle density at different body sites of Wan Strain Angora rabbits with high and low wool production (HWP and LWP) was investigated by histological analysis. Haematoxylin-eosin staining showed a higher hair follicle density in the skin of the HWP rabbits. The long noncoding RNA (IncRNA) profile was investigated by RNA sequencing, and 50 and 38 differentially expressed (DE) IncRNAs and genes, respectively, were screened between the HWP and LWP groups. A gene ontology analysis revealed that phospholipid, lipid metabolic, apoptotic, lipid biosynthetic, and lipid and fatty acid transport processes were significantly enriched. Potential functional IncRNAs that regulate lipid metabolism, amino acid synthesis, as well as the Janus kinase (JAK)-signal transducer and activator of transcription (STAT) and hedgehog signalling pathways, were identified. Consequently, five IncRNAs (LNC_002171, LNC_000797, LNC_005567, LNC_013595, and LNC_020367) were considered to be potential regulators of hair follicle density and development. Three DE IncRNAs and genes were validated by quantitative real-time polymerase chain reaction (q-PCR).
\end{abstract}

Conclusions: LncRNA profiles provide information on IncRNA expression to improve the understanding of molecular mechanisms involved in the regulation of hair follicle density.

Keywords: Skin, Hair follicle density, Wool production, Histological analysis, LncRNA expression, RNA sequencing, Angora rabbit

\section{Background}

The Angora rabbit is an economically important livestock breed in several countries, especially in China and France. Wool production is one of the most important traits in Angora rabbits. The fur quality of rabbits is largely dependent on hair density, and hair follicle density determines hair density $[1,2]$. For Angora rabbits under the same environmental conditions, gender, body site, and the month of age are closely related to wool fibre production [3]. Genetic

\footnotetext{
*Correspondence: hdwscience@163.com

Anhui Key Laboratory of Livestock and Poultry Product Safety Engineering, Institute of Animal Husbandry and Veterinary Medicine, Anhui Academy of Agricultural Sciences, Hefei 230031, Anhui, People's Republic of China
}

factors that influence wool fibre production are fibre diameter, length, fineness, and the fibre density [3-7]. The mean hair follicle density depends on the skin area. The development of wool follicles occurs during prenatal life and no new hair follicles are formed after birth, implying that hair density in an adult rabbit will depend on how much that particular body part grows after the formation of the hair follicles $[7,8]$. Correspondingly, hair follicle density and other wool characteristics are highly variable over the human and rabbit body [7-9]. The molecular mechanism underlying hair follicle density in rabbit skin and hair follicle development remains unclear.

(c) The Author(s). 2021 Open Access This article is licensed under a Creative Commons Attribution 4.0 International License, which permits use, sharing, adaptation, distribution and reproduction in any medium or format, as long as you give appropriate credit to the original author(s) and the source, provide a link to the Creative Commons licence, and indicate if changes were made. The images or other third party material in this article are included in the article's Creative Commons licence, unless indicated otherwise in a credit line to the material. If material is not included in the article's Creative Commons licence and your intended use is not permitted by statutory regulation or exceeds the permitted use, you will need to obtain permission directly from the copyright holder. To view a copy of this licence, visit http://creativecommons.org/licenses/by/4.0/. The Creative Commons Public Domain Dedication waiver (http://creativecommons.org/publicdomain/zero/1.0/) applies to the data made available in this article, unless otherwise stated in a credit line to the data. 
Hair follicle development is a complex morphogenetic process and undergoes periodic stages of growth (anagen), regression (catagen), and relative quiescence (telogen) [10-12]. The process of hair follicle formation and differentiation relies on many regulating molecules including messenger RNAs (mRNAs) and micro RNAs (miRNAs) [13-15], as well as a variety of signalling systems, such as the Wnt, Notch, bone morphogenetic protein (BMP), and fibroblast growth factor (FGF) pathways [16-21]. LncRNAs are RNA transcripts longer than $200 \mathrm{nu}-$ cleotides that lack open reading frames (ORF) and protein-coding capabilities [22]. They regulate protein-coding gene expression at posttranscriptional and transcriptional levels $[23,24]$. It is generally known that lncRNAs are also involved in the regulation of the hair follicle development and skin homeostasis [25-27]. RP11-766 N7.3, H19 and HOTAIR are specific lncRNAs that are involved in Wnt signalling to regulate hair follicle development [28]. Strand-specific RNA sequencing (ssRNA-seq) also showed that lncRNAs may be considered as potential candidate markers for further study on the molecular mechanisms of hair follicle initiation [29]. However, hair follicle density-related lncRNAs in rabbits have not been profiled so far.

In this study, the RNA-seq based approach was used to determine lncRNA expression levels in Angora rabbits with high wool production (HWP) and low wool production (LWP) after hair follicle density analysis. The results should provide fundamental resources to reveal the regulatory function of IncRNAs in hair follicle density in rabbits, as well as supply information for understanding human hair disorders such as hypotrichosis.

\section{Results}

Comparison of hair follicle density in high and low wool production rabbits

To characterize the hair follicle density, the follicle densities of the backs, abdomens, sides, and hips of Wan Strain Angora rabbits with HWP and LWP were compared (Fig. 1). A morphological analysis showed that the hair follicle densities of backs, abdomens, sides, and hips were higher in the HWP group (Fig. 1a, b, c, d) than in the LWP group (Fig. 1e, f, g, h). The results demonstrate that a high hair follicle density leads to high wool production in Wan Strain Angora rabbits.

\section{Sequencing and assembly}

Eight libraries of the HWP groups (H1, H2, H3, and H4) and LWP groups (L1, L2, L3, and L4) were constructed. For the HWP and LWP libraries, above 84,456,770 and 94, 769,312 clean reads per sample were obtained, respectively (Table 1). Above 89.19 and $89.02 \%$ of the reads were aligned with the rabbit reference genome uniquely located by above 77.55 and $75.67 \%$ of the clean reads for the HWP and LWP libraries, respectively. Above 17,380,601 (52.78\%) and 21,898,377 (46.66\%) reads, respectively, were identified as protein-coding mRNAs of the HWP and LWP groups (Additional file 1: Table S1). The other types of reads amounted to $12,349,910$ (36.07\%) and 16,461,100 (39.19\%) for HWP and LWP groups, respectively, and these reads may include lncRNAs (Additional file 1: Table S1).

\section{Characterization of IncRNAs in rabbit skin tissue}

The RNA-seq analysis produced 22,136 lncRNAs (Additional file 2: Table S2). The lncRNA transcripts included 10,692 lincRNAs (48.3\%), 2612 antisense lncRNAs (11.8\%), and 8832 intronic lncRNAs (39.9\%) (Fig. 2a).

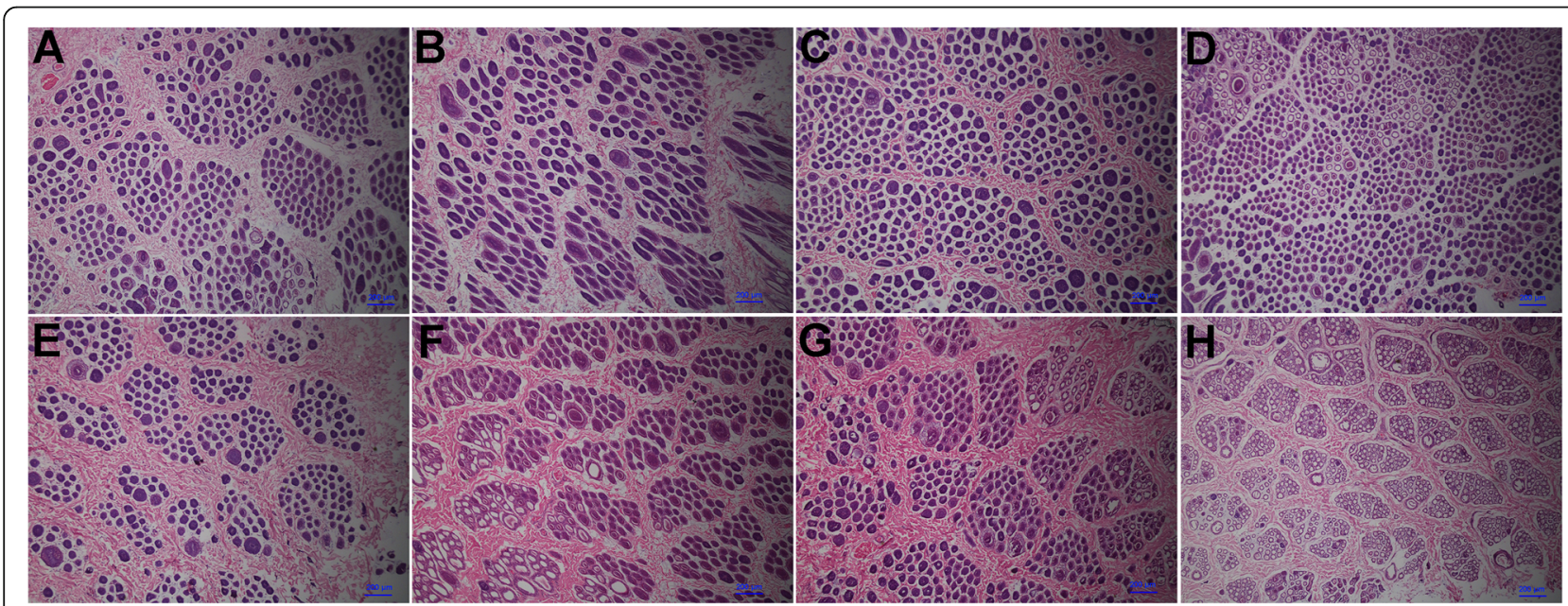

Fig. 1 The histological observation of skin tissue from Wan Strain Angora rabbits with HWP and LWP. $\mathbf{a}, \mathbf{b}, \mathbf{c}$, d Transverse section of the backs, abdomens, sides, and hips of Wan Strain Angora rabbits with HWP. e, $\mathbf{f}, \mathbf{g}, \mathbf{h}$ Transverse section of the backs, abdomens, sides, and hips of Wan Strain Angora rabbits with LWP. HWP, High wool production; LWP, Low wool production. Bars $=200 \mu \mathrm{m}$ 
Table 1 The analyses of reads mapped to the rabbit reference genome

\begin{tabular}{|c|c|c|c|c|c|c|c|c|}
\hline Sample name & $\mathrm{H} 1$ & $\mathrm{H} 2$ & H3 & $\mathrm{H} 4$ & L1 & L2 & L3 & L4 \\
\hline Total reads & $95,426,664$ & $84,456,770$ & $149,301,000$ & $89,038,716$ & $123,865,064$ & $94,769,312$ & $109,570,388$ & $130,245,954$ \\
\hline Total mapped & $\begin{array}{l}85,943,449 \\
(90.06 \%)\end{array}$ & $\begin{array}{l}75,328,473 \\
(89.19 \%)\end{array}$ & $\begin{array}{l}133,972,487 \\
(89.73 \%)\end{array}$ & $\begin{array}{l}79,823,704 \\
(89.65 \%)\end{array}$ & $\begin{array}{l}110,263,589 \\
(89.02 \%)\end{array}$ & $\begin{array}{l}84,819,962 \\
(89.5 \%)\end{array}$ & $\begin{array}{l}99,272,110 \\
(90.6 \%)\end{array}$ & $\begin{array}{l}117,162,667 \\
(89.95 \%)\end{array}$ \\
\hline Multiple mapped & $\begin{array}{l}11,938,587 \\
(12.51 \%)\end{array}$ & $\begin{array}{l}9,315,870 \\
(11.03 \%)\end{array}$ & $\begin{array}{l}13,827,931 \\
(9.26 \%)\end{array}$ & $\begin{array}{l}10,659,938 \\
(11.97 \%)\end{array}$ & $\begin{array}{l}16,534,984 \\
(13.35 \%)\end{array}$ & $\begin{array}{l}9,777,660 \\
(10.32 \%)\end{array}$ & $\begin{array}{l}14,500,967 \\
(13.23 \%)\end{array}$ & $\begin{array}{l}11,066,700 \\
(8.5 \%)\end{array}$ \\
\hline Uniquely mapped & $\begin{array}{l}74,004,862 \\
(77.55 \%)\end{array}$ & $\begin{array}{l}66,012,603 \\
(78.16 \%)\end{array}$ & $\begin{array}{l}120,144,556 \\
(80.47 \%)\end{array}$ & $\begin{array}{l}69,163,766 \\
(77.68 \%)\end{array}$ & $\begin{array}{l}93,728,605 \\
(75.67 \%)\end{array}$ & $\begin{array}{l}75,042,302 \\
(79.18 \%)\end{array}$ & $\begin{array}{l}84,771,143 \\
(77.37 \%)\end{array}$ & $\begin{array}{l}106,095,967 \\
(81.46 \%)\end{array}$ \\
\hline Reads map to ' $+{ }^{\prime}$ & $\begin{array}{l}36,872,804 \\
(38.64 \%)\end{array}$ & $\begin{array}{l}32,897,302 \\
(38.95 \%)\end{array}$ & $\begin{array}{l}60,000,375 \\
(40.19 \%)\end{array}$ & $\begin{array}{l}34,636,589 \\
(38.9 \%)\end{array}$ & $\begin{array}{l}46,454,860 \\
(37.5 \%)\end{array}$ & $\begin{array}{l}37,454,686 \\
(39.52 \%)\end{array}$ & $\begin{array}{l}42,357,439 \\
(38.66 \%)\end{array}$ & $\begin{array}{l}52,928,464 \\
(40.64 \%)\end{array}$ \\
\hline Reads map to '-' & $\begin{array}{l}37,132,058 \\
(38.91 \%)\end{array}$ & $\begin{array}{l}33,115,301 \\
(39.21 \%)\end{array}$ & $\begin{array}{l}60,144,181 \\
(40.28 \%)\end{array}$ & $\begin{array}{l}34,527,177 \\
(38.78 \%)\end{array}$ & $\begin{array}{l}47,273,745 \\
(38.17 \%)\end{array}$ & $\begin{array}{l}37,587,616 \\
(39.66 \%)\end{array}$ & $\begin{array}{l}42,413,704 \\
(38.71 \%)\end{array}$ & $\begin{array}{l}53,167,503 \\
(40.82 \%)\end{array}$ \\
\hline Non-splice reads & $\begin{array}{l}56,778,516 \\
(59.5 \%)\end{array}$ & $\begin{array}{l}51,943,073 \\
(61.5 \%)\end{array}$ & $\begin{array}{l}89,625,539 \\
(60.03 \%)\end{array}$ & $\begin{array}{l}51,395,189 \\
(57.72 \%)\end{array}$ & $\begin{array}{l}74,099,166 \\
(59.82 \%)\end{array}$ & $\begin{array}{l}57,787,882 \\
(60.98 \%)\end{array}$ & $\begin{array}{l}65,280,836 \\
(59.58 \%)\end{array}$ & $\begin{array}{l}79,655,006 \\
(61.16 \%)\end{array}$ \\
\hline Splice reads & $\begin{array}{l}17,226,346 \\
(18.05 \%)\end{array}$ & $\begin{array}{l}14,069,530 \\
(16.66 \%)\end{array}$ & $\begin{array}{l}30,519,017 \\
(20.44 \%)\end{array}$ & $\begin{array}{l}17,768,577 \\
(19.96 \%)\end{array}$ & $\begin{array}{l}19,629,439 \\
(15.85 \%)\end{array}$ & $\begin{array}{l}17,254,420 \\
(18.21 \%)\end{array}$ & $\begin{array}{l}19,490,307 \\
(17.79 \%)\end{array}$ & $\begin{array}{l}26,440,961 \\
(20.3 \%)\end{array}$ \\
\hline $\begin{array}{l}\text { Reads mapped in } \\
\text { proper pairs }\end{array}$ & $\begin{array}{l}69,994,050 \\
(73.35 \%)\end{array}$ & $\begin{array}{l}62,138,530 \\
(73.57 \%)\end{array}$ & $\begin{array}{l}113,304,356 \\
(75.89 \%)\end{array}$ & $\begin{array}{l}65,315,796 \\
(73.36 \%)\end{array}$ & $\begin{array}{l}88,424,106 \\
(71.39 \%)\end{array}$ & $\begin{array}{l}70,592,926 \\
(74.49 \%)\end{array}$ & $\begin{array}{l}80,480,580 \\
(73.45 \%)\end{array}$ & $\begin{array}{l}100,326,142 \\
(77.03 \%)\end{array}$ \\
\hline
\end{tabular}

The average length of the novel lncRNAs was considerably shorter than the mRNAs, but longer than the known lncRNAs (Fig. 2b). The exon numbers of the novel lncRNAs were less than the mRNAs while greater than the known lncRNAs (Fig. 2c). In addition, ORF size in novel lncRNAs was longer than that in annotated lncRNAs, but shorter than that in protein-coding genes (Fig. 2d).
Long noncoding RNAs and mRNAs expression profiles in rabbit skin tissue

The results showed that the expression levels of mRNAs were higher than those of IncRNAs (Additional file 3: Fig. S1). Fifty and thirty-eight differentially expressed (DE) lncRNAs and genes, respectively, were screened in the LWP and HWP groups (Additional file 4: Table S3, Table S4). Of these lncRNAs and genes, 15 lncRNAs
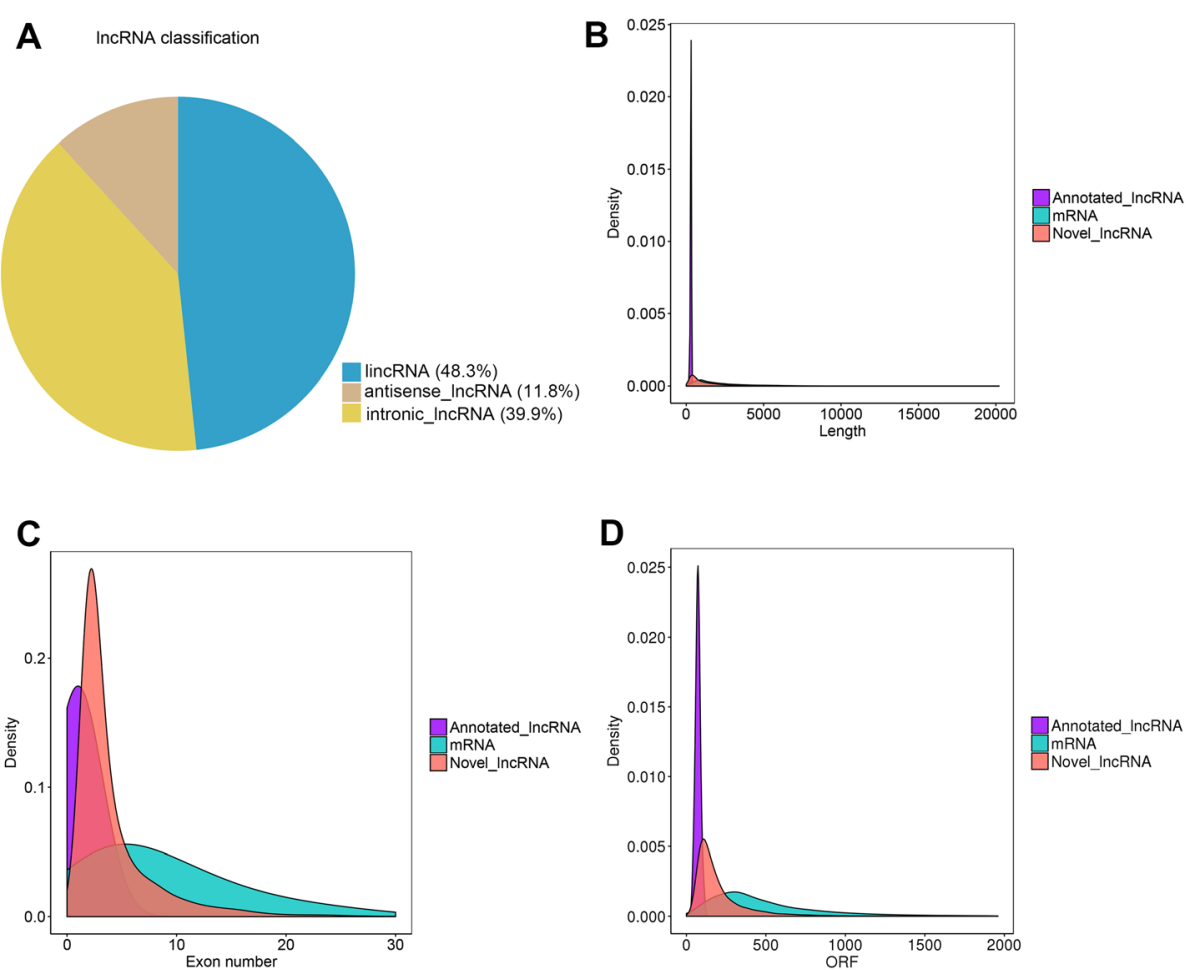

Fig. 2 Characterization of IncRNAs transcribed from Wan Strain Angora rabbits. a The IncRNA classification in Wan Strain Angora rabbits. b Length distribution of IncRNAs and protein-coding transcripts. c Exon number distribution per the transcript of IncRNAs and protein-coding transcripts. d ORF number distribution per the transcript of IncRNAs and protein-coding transcripts. ORF, open reading frames 
and 21 genes were upregulated, and 35 lncRNAs and 17 genes were downregulated in the LWP group. Hierarchical cluster analysis of IncRNA and mRNA expression levels between LWP and HWP groups revealed distinct expression patterns (Fig. 3).

\section{Long noncoding RNA target prediction and functional analysis}

The potential target genes of lncRNAs were predicted accordingly their position (co-location) and expression correlation (co-expression) with the protein-coding genes. Gene ontology (GO) analysis was applied to investigate the potential functions of the lncRNAs' colocation and co-expression mRNAs on the regulation of hair follicle development and wool production (Fig. 4). The significance of enrichment of each GO term was assessed by $P$-value $<0.05$, and then the GO terms were filtered by the enrichment scores (- $\operatorname{Lg} P$-value). The GO enrichment analysis showed that the IncRNAs' colocation mRNAs were significantly enriched in phospholipid, lipid metabolic, and epithelial cell apoptotic processes in the biological process category (Fig. 4a), while co-expression mRNAs were significantly enriched in the cellular metabolic, lipoprotein, lipid biosynthetic, lipid, and fatty acid transport processes (Fig. 4b). The Kyoto Encyclopedia of Genes and Genomes (KEGG) pathway analysis offered a reliable way of elucidating the candidate biological pathways that the integrated target genes were enriching. The cytokine-cytokine receptor interaction, chemokine signalling pathway and JAK-STAT signalling pathway were significantly involved in lncRNAs' co-location mRNAs (Fig. 5a). In addition, pathways related to the biosynthesis of amino acids, arginine and proline metabolism, ether lipid metabolism, and the hedgehog signalling pathway were highly enriched by lncRNAs' co-expression mRNAs (Fig. 5b). Therefore, the target genes of the DE IncRNAs between the LWP and HWP groups were related to lipid metabolism, amino acid synthesis, JAK-STAT, and the hedgehog signalling pathway. According to the functional enrichment analyses, five DE lncRNAs (LNC_002171, LNC_000797, LNC_005567, LNC_013595, and LNC_ 020367) were selected to construct regulatory networks (Fig. 6). LNC_002171 and LNC_000797 were involved in JAK-STAT and the hedgehog signalling pathway.

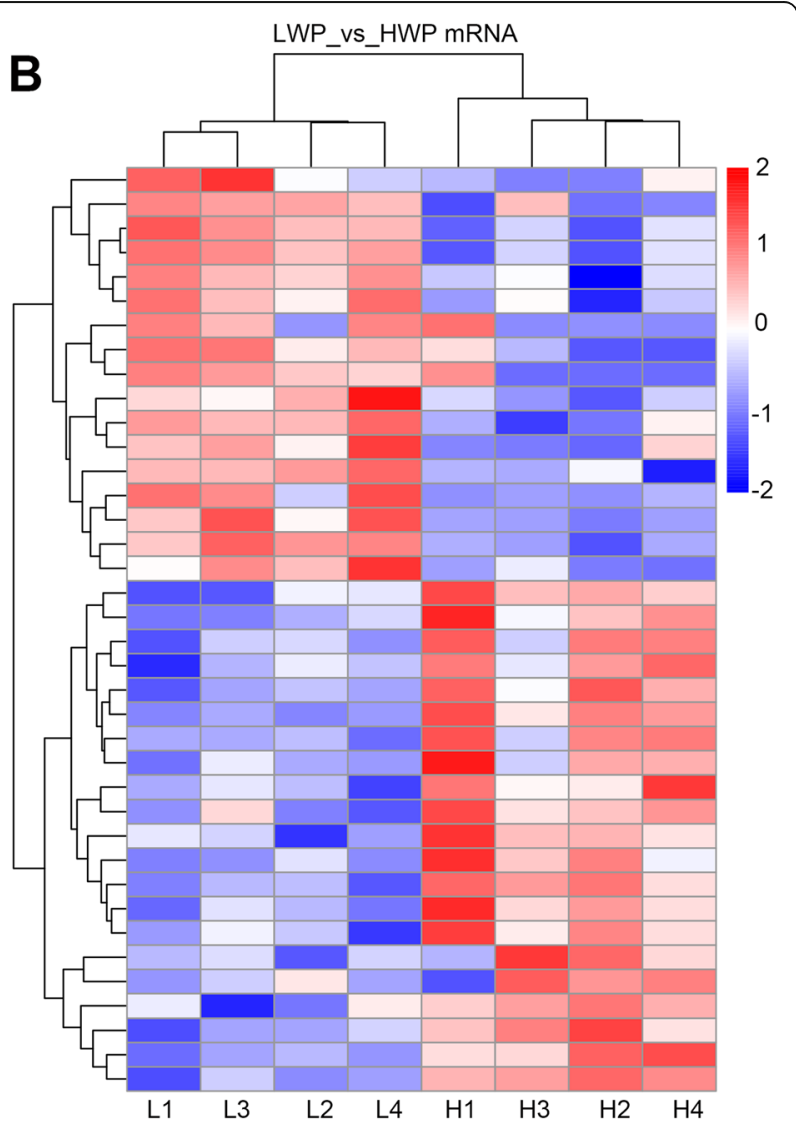

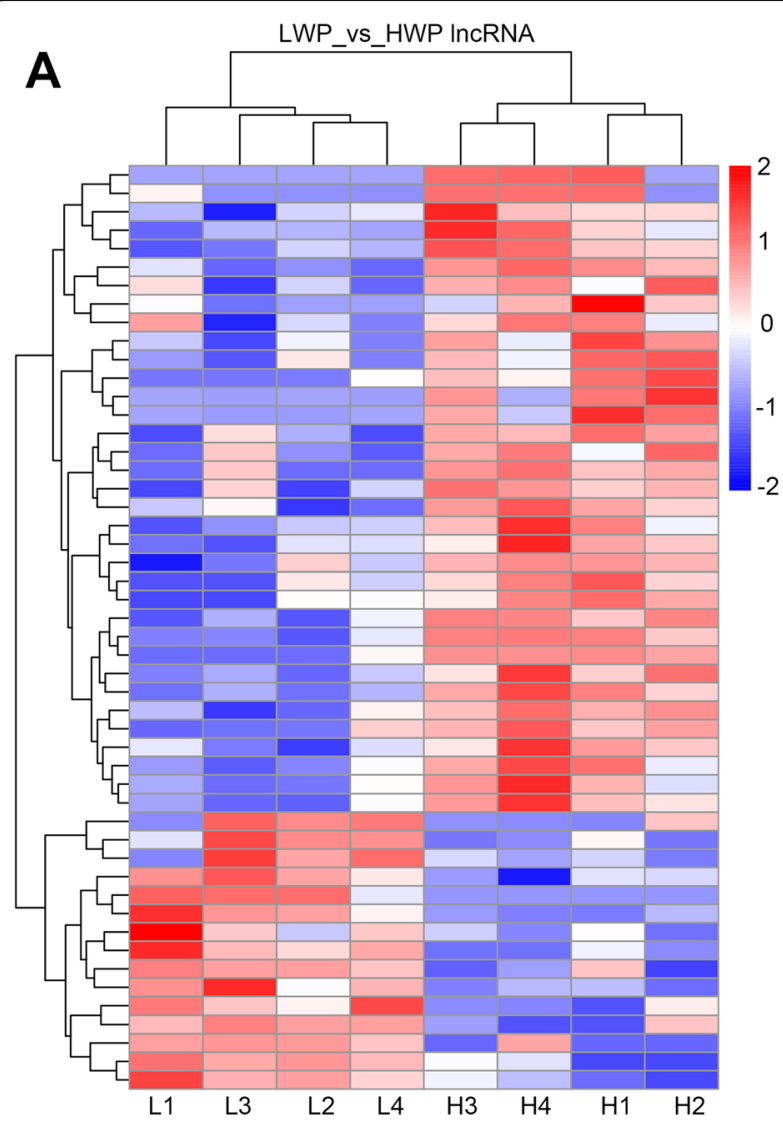

Fig. 3 Heatmaps of differentially expressed IncRNAs and mRNAs between HWP and LWP rabbits. a IncRNAs. b mRNAs. "L" and "H" represent low wool production and high wool production groups, respectively. "Red" and "blue" indicate up-regulated and down-regulated transcripts, respectively. HWP, High wool production; LWP, Low wool production 


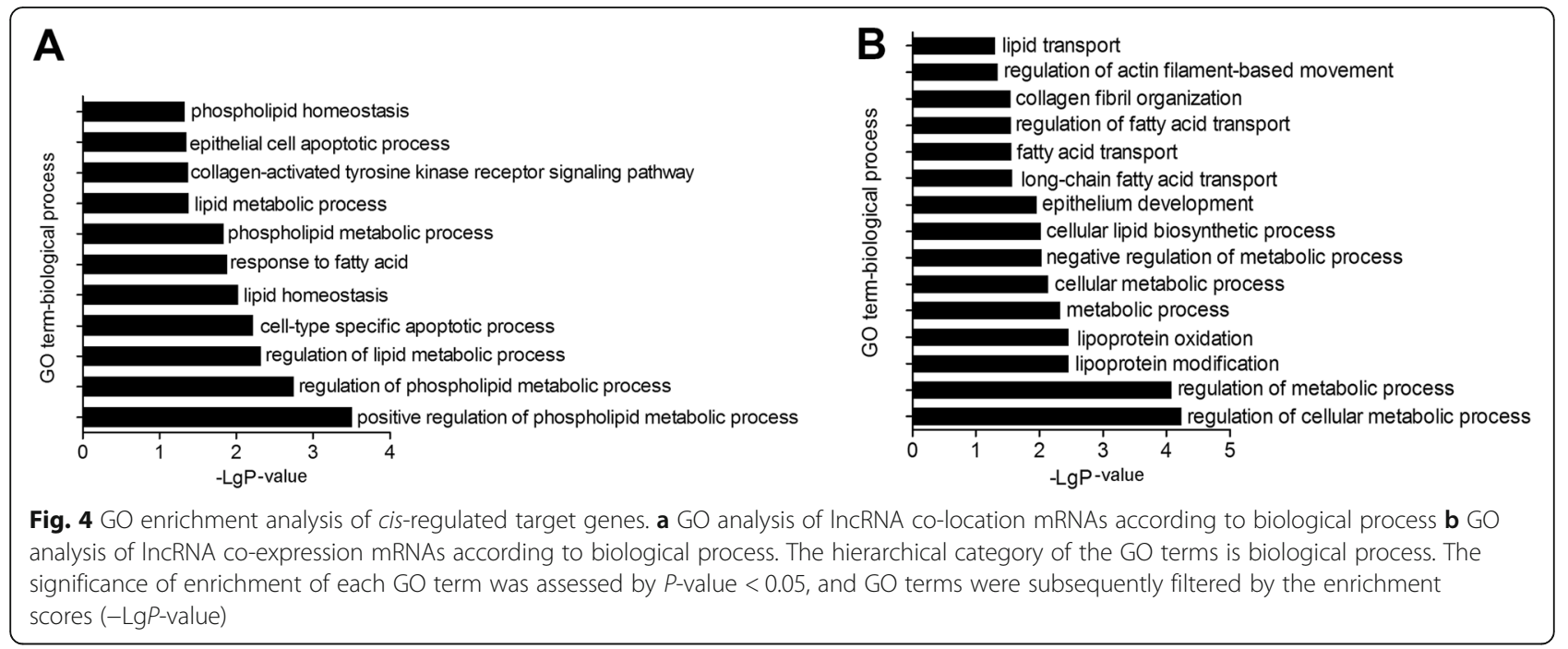

Validation of DE IncRNAs and mRNAs with quantitative real-time polymerase chain reaction

To validate the RNA-Seq results, LNC_000797, LNC 013595, LNC_020367, KRTAP15-1, TCHHL1, and $A L O X 15 B$ were selected and their expression patterns in the LWP and HWP groups were examined by q-PCR. The results showed that the three DE lncRNAs and mRNAs were differentially expressed in the LWP and HWP groups. In addition, they exhibited a similar trend in the results of the RNA-seq and the q-PCR (Fig. 7). Therefore, the fragments per kilobase of transcript per million mapped reads (FPKM) obtained from RNA-seq could be reliably used to determine lncRNA and mRNA expression in the LWP and HWP groups.

\section{Discussion}

Wool density is one of the most important indices to evaluate the quality of the fur of the Wan Strain Angora rabbit [6]. Hair follicle density determines wool density [1]. The quality of fur is associated mainly with the traits of the hair follicles [30]. To characterize the hair follicle density, the follicle density of the backs, abdomens, sides, and hips of Wan Strain Angora rabbits with HWP and LWP was compared (Fig. 1). A morphological analysis showed that the hair follicle density of backs,

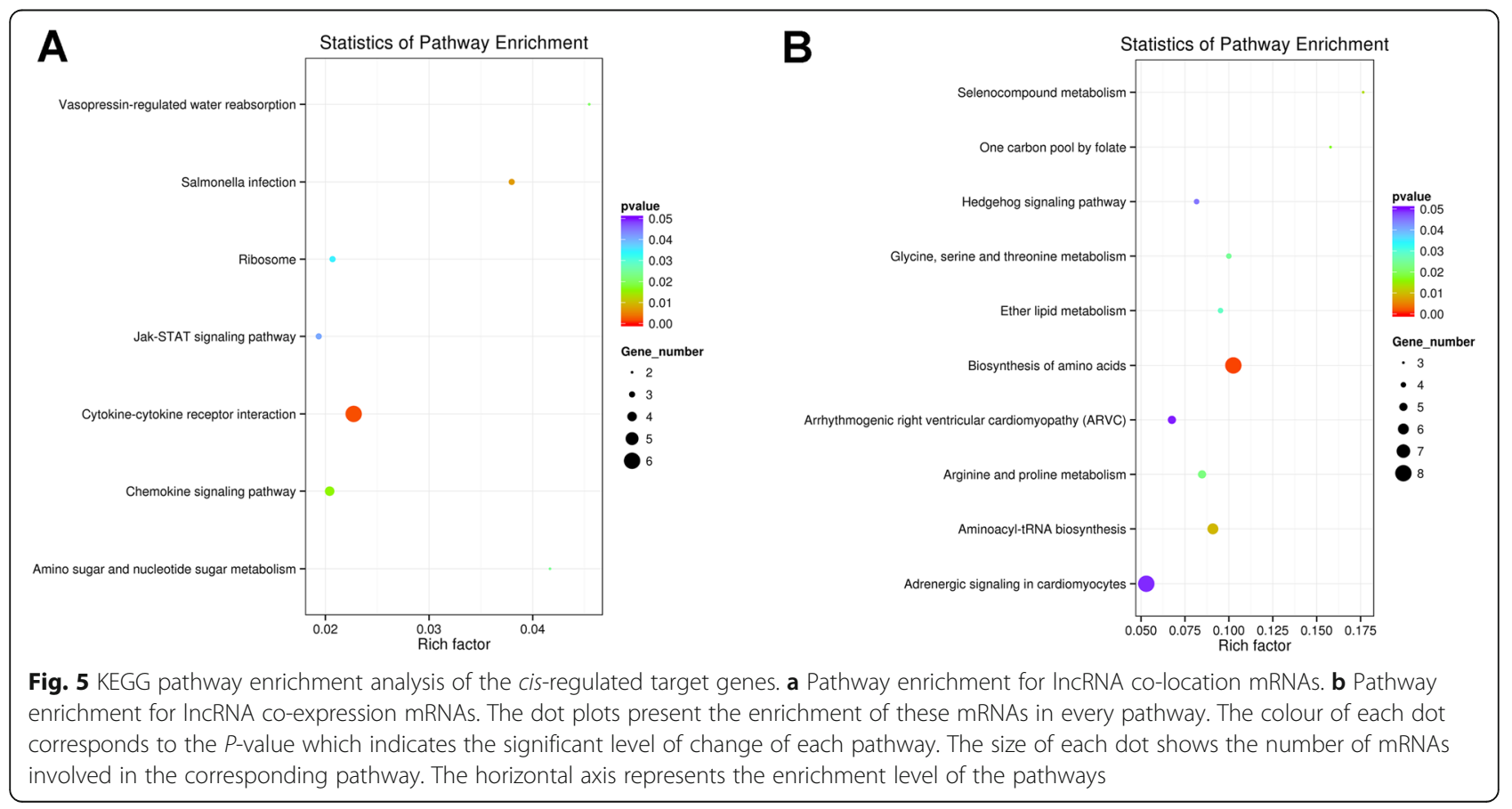




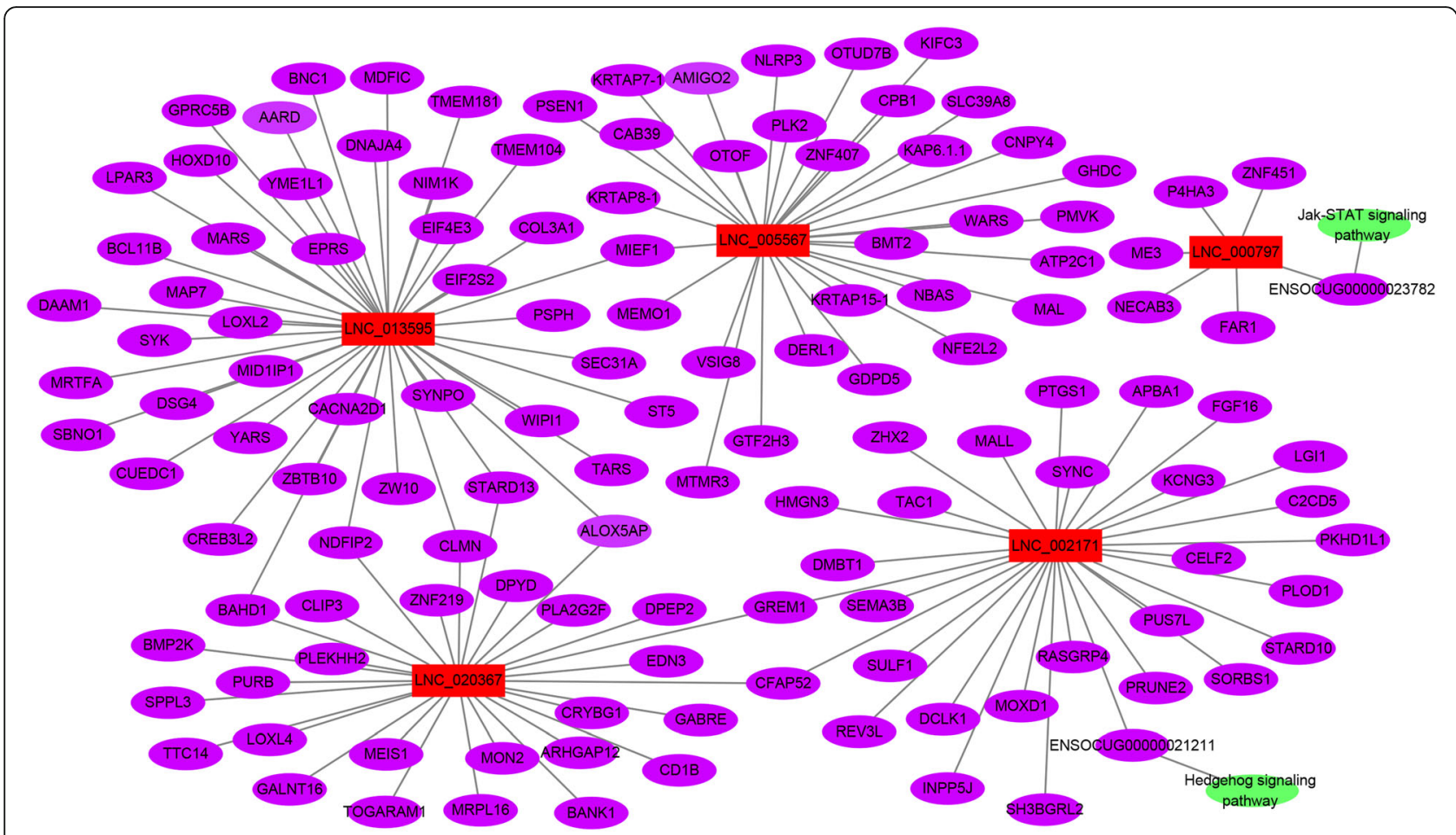

Fig. 6 Regulatory networks between IncRNA and mRNA. The purple ellipse represents mRNAs targeted by IncRNAs, the rectangle represents IncRNAs, and the green ellipse represents pathways enriched by mRNAs

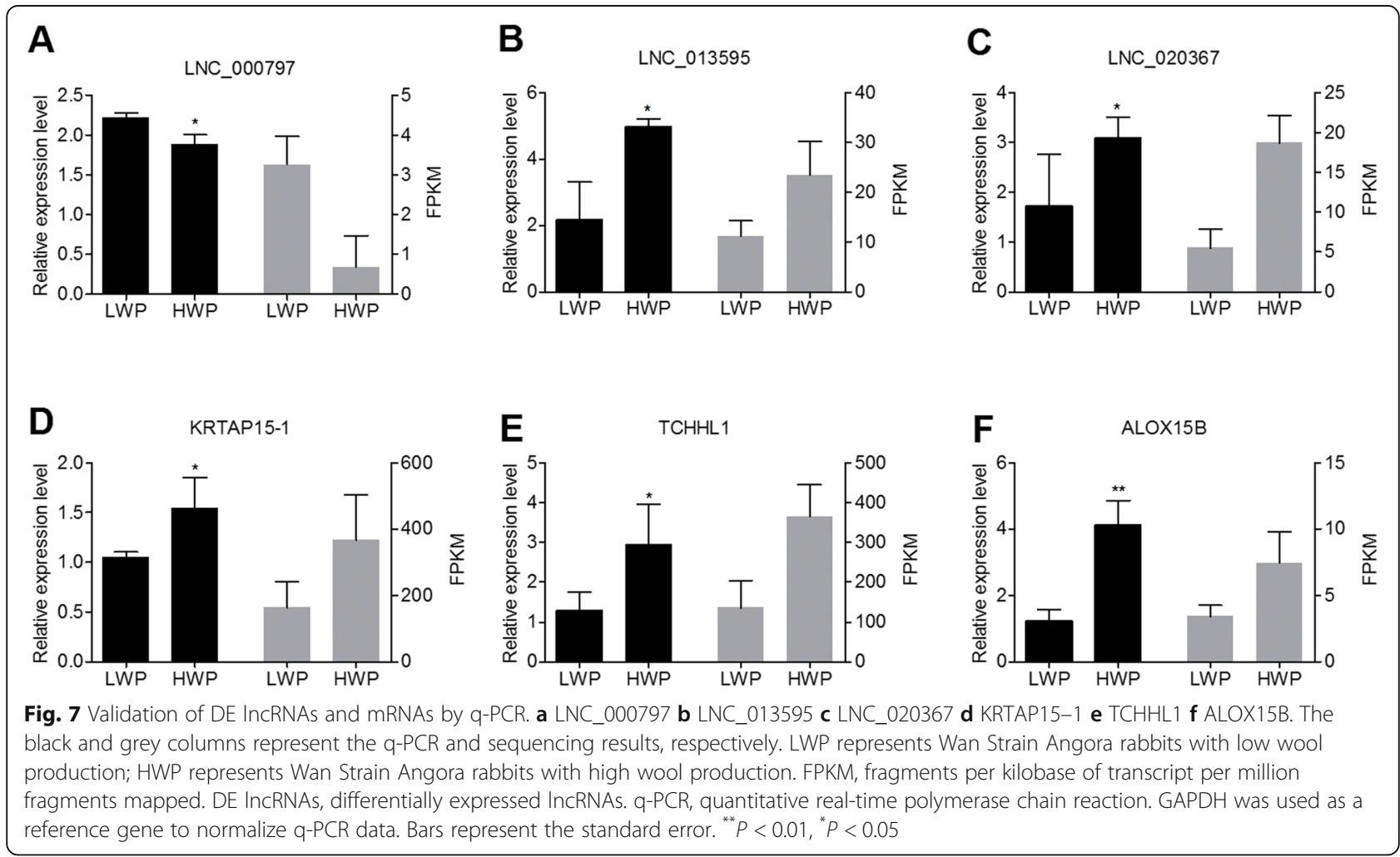


abdomens, sides, and hips of the HWP group was higher compared to the LWP group (Fig. 1). The results demonstrated that high hair follicle density contributed to high wool production in the Wan Strain Angora rabbit. In French Angora rabbits, divergent selection of total fleece weight led to a positive difference of 0.55 genetic standard deviation for secondary to primary follicle ratio $(\mathrm{S} / \mathrm{P})$, although a low genetic correlation existed between them [31].

The formation of hair follicles is divided into prenatal hair morphogenesis and the postnatal hair cycle [32]. Once established during embryogenesis, hair follicle density is permanently fixed in postnatal life, and the hair follicle location eventually becomes fixed as a result of anchoring in the subcutis [12]. LncRNAs are widely involved in various biological processes, including the hair follicle cycle [33, 34]. The lncRNA and mRNA expression profiles were compared in the dorsal skin of LWP and HWP rabbits, and 50 and 38 DE lncRNAs and genes were obtained, respectively. These lncRNAs and genes might play crucial roles in regulating hair follicle density, and their differential expression might be the reason for differences in hair follicle density and wool production between HWP and LWP rabbits. Liu et al. (2020) analysed the miRNA effect on hair follicle density in the Rex rabbit [35], but lncRNA related to hair density in rabbits has only been done in the present study.

The GO analysis showed that the DE IncRNAs are potential regulators of phospholipid, lipid metabolic, epithelial cell apoptotic, lipid biosynthetic, and lipid and fatty acid transport processes. Keratin-associated proteins (KRTAPs) play a critical role in cross-linking the keratin intermediate filaments to build a hair shaft [36]. KRTAP7-1, KRTAP8-1, and KRTAP15-1 were predicted as the targets of LNC_005567 in this study. KRTA $P 7-1$ is involved in supporting the mechanical strength and shape of hair [36]. KRTAP15-1 is expressed in secondary follicles in the skin and associated with fibre diameter [37]. COL3A1 and LOXL4 were the target genes of LNC_013595 and LNC_020367, respectively. COL3A1 is one of collagens forming different extracellular matrix (ECM) components [38]. The lysyl oxidase like 4 (LOLX4) enzyme is responsible for initiating covalent cross-linking in collagen fibrils and is involved in providing additional mechanical strength to the ECM $[39,40]$. The amount of ECM per cell contributes to the volume of the dermal papilla [41]. Hedgehog and JAKSTAT signalling pathway were significantly enriched by target genes ENSOCUG00000021211 and ENSOCUG00000023782 of LNC_002171 and LNC_000797, respectively. The hedgehog signalling pathway is correlated to the initiation of hair follicle formation and is a pivotal growth signal for dermal papilla maturation and growth [12, 42, 43]. The JAK-STAT signalling pathway is involved in maintaining the quiescence of hair follicles during telogen [44], and JAK-STAT inhibition contributes to the promotion of hair growth and the activation of hair follicle stem cells [45]. These findings demonstrate that LNC_002171, LNC_000797, LNC_005567, LNC_013595, and LNC_020367 are potentially important regulators of hair follicle density and development.

TCHHL1 is a hair-specific protein given its high expression in scalp and chin skin [46]. TCHHL1 was identified in a genome-wide association study (GWAS) to have a significant association with hair shape within the top-associated single nucleotide polymorphisms (SNPs) (rs17646946), and showed nominally significant association with hair curliness [47]. ALOX15B is restricted to terminally differentiating keratinocytes (in particular the stratum granulosum) and 8(S)-lipoxygenase activity seems to be involved in terminal differentiation of mouse epidermis [48]. Clements et al. (2012) identified reduced expression of $A L O X 15 B$ gene in ankyloblepharon-ectodermal defects-clefting (AEC) syndrome skin, with downregulated genes (KRT25 and KRT27) encoding keratins involved in the morphogenesis of hair follicles [49]. Thus, in combination with the current research, three genes may participate in the regulation of hair follicle density in Angora rabbits. The results of qPCR of LNC_000797, LNC_013595, LNC_020367, KRTA P15-1, TCHHL1, and ALOX15B showed similar expression patterns between RNA-Seq and q-PCR, demonstrating the reliability of these data.

\section{Conclusions}

In conclusion, differences in the histology and lncRNA profiles of skin were identified in HWP and LWP rabbits. The histological analysis showed a higher hair follicle density in HWP rabbits. The analyses of lncRNA profiles identified candidate lncRNAs involved in lipid metabolism, apoptosis, and hair follicle development. Further studies are required to investigate the roles of candidate lncRNAs in hair follicle density to improve rabbit breeding programmes.

\section{Methods}

\section{Animals}

All animals were procured from the rabbit farm and acquired an approval from the farm owner in the Animal Husbandry and Veterinary Medicine Institute of Anhui Academy of Agriculture Sciences, Hefei, Anhui, China. Sixty Wan Strain Angora rabbits (about 1 year old) were reared in the same conditions with regular pellets and water ad libtum. The wool weight of five successive collections using electric shears in 1 year from adult rabbits were determined. The 60 rabbits were divided into two populations designated as high wool production (HWP) 
and low wool production (LWP) according to wool production. The average wool weights showed remarkable difference (HWP: $401.3 \pm 36.5 \mathrm{~g}$ vs LWP: $314.4 \pm 29.2 \mathrm{~g}$, $P<0.001)$. Finally, four rabbits with high and low wool production $(430.1 \pm 16.5 \mathrm{~g}$ vs $291.6 \pm 13.3 \mathrm{~g}, P<0.0001)$ were selected for the present study, respectively (Additional file 5: Table S5). The 52 remaining rabbits were reared like ordinary rabbits for wool production.

\section{Sample collection, preparation for histological examination}

The eight rabbits selected (four rabbits with high wool production, four rabbits with low wool production) were anesthetized by injecting $0.7 \%$ pentobarbital sodium $(6$ $\mathrm{ml} / \mathrm{kg}$ ) into ear vein of the rabbits before sampling. Skin tissue samples $\left(1 \mathrm{~cm}^{2}\right)$ were collected from the backs, abdomens, sides and hips at the fourth week after plucking for histological analysis. Each skin sample was cut apart into two and then one piece was prepared and then subjected to histological analysis as our previous study [13]. The iodine solution was smeared on the resultant lesion to prevent bacterial infection. After the experiment, the rabbits were retained in the rabbit farm and reared and protected from external stimuli.

\section{CDNA library construction and sequencing}

Under anesthesia, skin samples from the back of the eight rabbits selected (four rabbits with high wool production and four rabbits with low wool production; $430.1 \pm 16.5 \mathrm{~g}$ vs $291.6 \pm 13.3 \mathrm{~g}, P<0.0001)$ were collected at the fourth week after plucking for RNA-seq. The skin samples were firstly frozen in liquid nitrogen immediatelly after cutting and then stored at $-80^{\circ} \mathrm{C}$ before RNA extration. Whole RNA was extracted from the skin of HWP rabbits (designated as $\mathrm{H} 1, \mathrm{H} 2, \mathrm{H} 3$, and H4) and LWP rabbits (designated as L1, L2, L3, and L4) using TRIzol reagent (Invitrogen, Carlsbad, CA, USA) according to the manufacturer's instructions. The samples were sent to the Beijing Novogene Co., LTD with drikold. The purity and integrity of RNA was evaluated using the NanoPhotometer spectrophotometer (Implen, CA, USA) and Agilent 2100 Bioanalyzer (Agilent Technologies, CA, USA). The RNA was purified by removing rRNA, fragmented randomly, and converted to double cDNA, then were ligated with NEBNext adaptors. Finally, eight libraries were created by PCR using the NEBNext $^{\circ}$ Ultra $^{\text {Tx }}$ Directional RNA Library Prep Kit (NEB, USA), quantified with Qubit2.0, and sequenced on an Illumina HiSeq 2500 platform (Illumina, San Diego, CA, USA).

\section{Mapping, assembling and screening}

Impurity data were removed from the raw reads and more than $12 \mathrm{~Gb}$ clean reads per sample were generated.
The clean reads with high quality were then aligned using HISAT2 to the rabbit reference genome (https:// www.ncbi.nlm.nih.gov/genome/?term=Rabbit) sequence. The mapped reads of each sample were assembled by StringTie (v2.0.4) [50]. The candidate lncRNAs were distinguished according to its sequence charecteristics (length $>200 \mathrm{nt}$ and noncoding potential) and meantime transcripts predicted with coding potential were filtered out by multiple tools. Conservative and comparative analyses were done between lncRNAs and mRNAs, and classification of lncRNAs was also analyzed.

\section{Quantification, target prediction and function analysis}

The expression levels of the lncRNAs and mRNAs in each sample were calculated by fragments per kilobase of transcript per million fragments mapped (FPKM). Differential expression between LWP and HWP groups was analyzed by using cuffdiff (https://www.genepattern.org/ modules/docs/Cuffdiff/7), and the threshold was set as $\mid \log 2$ (Fold Change) $\mid \geq 1$ and $P$ value $<0.05$. Target prediction was conducted by searching coding genes $100 \mathrm{~kb}$ up- and down-stream of lncRNAs (co-location) and analyzing co-expression relationship (pearson correlation) of mRNAs to lncRNAs. Then, GO and KEGG enrichment analyses were performed on targets and the function of key lncRNAs were predicted. GOseq R package [51] and KOBAS (http://www.genome.jp/kegg/) were used to conduct GO and KEGG enrichment analyses.

\section{Quantitative real-time polymerase chain reaction}

Three candidate lncRNAs and mRNAs were selected from the list of DE lncRNAs and DEGs for validation, and the relative expression level was determined by qPCR on LightCycler 96 (Roche, Switzerland) using TransStart Green qPCR SuperMix (Transgen, Beijing, China) as our previous study [13]. The primers for qPCR are listed in Additional file 6: Table S6. The reaction was performed in triplicates for each sample (HWP group: H1, H2, H3, and H4; LWP group: L1, L2, L3, and L4). The $2^{-\triangle \Delta C T}$ method was used to determine the relative expression level of each gene.

\section{Statistical analyses}

Student's $t$-test with two-sided was used in statistical comparisons in wool weight between HWP and LWP groups and RNA expression. Error bars represent the mean \pm standard deviation (SD) as determined using GraphPad Prism 5 (GraphPad Sofware, Inc., La Jolla, CA, USA). A $P$ value $<0.05$ were considered the criterion for statistical significance.

\section{Supplementary Information}

The online version contains supplementary material available at https://doi. org/10.1186/s12864-021-07398-4. 
Additional file 1: Table S1. The analyses of reads mapped to the Rabbit reference genome.

Additional file 2: Table S2. List of 22,136 annotated IncRNA. Additional file 3: Figure S1. Expression level analysis of the IncRNAs and protein-coding genes.

Additional file 4: Table S3, Table S4. Differentially expressed IncRNAs and genes between the LWP and HWP groups, respectively. HWP, High wool production; LWP, Low wool production.

Additional file 5: Table S5. The wool production of the rabbits. " $L$ " and "H" represent low wool production and high wool production groups, respectively.

Additional file 6: Table S6. Primers for $\mathrm{q}-\mathrm{PCR} . \mathrm{F}^{1}$, forward primer. $\mathrm{R}^{2}$, reverse primer.

\section{Abbreviations}

BMP: Bone morphogenetic protein; DE: Differentially expressed; ECM: Extracellular matrix; FDR: False discovery rate; FGF: Fibroblast growth factor; FPKM: Fragments per kilobase of transcript per million fragments mapped; GO: Gene Ontology; HE: Haematoxylin-eosin; HWP: High wool production; JAK: Janus kinase; KEGG: Kyoto Encyclopedia of Genes and Genomes; IncRNA: long noncoding RNA; LWP: Low wool production; ORF: Open reading frames; q-PCR: Quantitative real-time polymerase chain reaction; SD: Standard deviation; ssRNA-seq: Strand-specific RNA sequencing; STAT: signal transducer and activator of transcription

\section{Acknowledgments}

Not Applicable.

\section{Authors' contributions}

HLZ, DWH, and HSD conceived the study. HLZ, DWH, and XFW performed sample collection and total RNA preparation. XWZ and YXQ performed the q-PCR validation. HSD and DWH conducted the data analysis and prepared figures and tables. HSD and DWH wrote the manuscript. All authors read and approved the final manuscript.

\section{Funding}

This work was supported by the earmarked fund for China Agriculture Research System (Grant No.: CARS-43-A-4) and Anhui Provincial Natural Science Foundation (Grant No.: 2008085QC137). These funding bodies had no role in the design of the study, sample collection, analysis or interpretation of data and in writing the manuscript.

\section{Availability of data and materials}

The data was presented in the manuscript and the supporting materials. The raw reads data was submitted to the Short Read Archive (SRA) under the accession number SRP299630 and BioProject accession number PRJNA688082 (https://www.ncbi.nlm.nih.gov/sra/PRJNA688082).

\section{Ethics approval and consent to participate}

The present study was carried out in strict accordance with relevant guidelines and regulations by the Ministry of Agriculture of the People's Republic of China. All experimental protocols were approved by the Ethics Committee of Anhui Academy of Agricultural Sciences.

\section{Consent for publication}

Not applicable.

\section{Competing interests}

The authors declare that they have no competing interests.

Received: 23 July 2020 Accepted: 19 January 2021

Published online: 28 January 2021

\section{References}

1. Paus R, Cotsarelis G. The biology of hair follicles. N Engl J Med. 1999;341(7): 491-7.
2. Sun H, Zhang Y, Bai L, Wang Y, Yang L, Su W, et al. Heat stress decreased hair follicle population in rex rabbits. J Anim Physiol Anim Nutr. 2019;103(2): 501-8.

3. Lanszki J, Thébault RG, Allain D, Szendrõ Z, Eiben C. The effects of melatonin treatment on wool production and hair follicle cycle in angora rabbits. Anim Res. 2001;50(1):79-89.

4. Rafat SA, Allain D, Rochambeau HD. Genetic description of a divergent selection experiment in angora rabbits with overlapping generations. J Anim Breed Genet. 2009;26(3):189-97.

5. Rahman SU, Wang X, Yu L. Observations on biotic parameters of angora rabbit breed under controlled conditions in different housing systems. Vet World. 2018;11(1):88-92.

6. Chen SJ, Liu T, Liu YJ, Dong B, Gu ZL. Identification of single nucleotide polymorphisms in the CCNA2 gene and its association with wool density in Rex rabbits. Genet Mol Res. 2011;10(4):3365-70.

7. Otberg N, Richter H, Schaefer H, Blume-Peytavi U, Sterry W, Lademann J. Variations of hair follicle size and distribution in different body sites. J Invest Dermatol. 2004;122(1):14-9.

8. Jönsson EH, Bendas J, Weidner K, Wessberg J, Olausson H, Wasling HB, et al. The relation between human hair follicle density and touch perception. Sci Rep. 2017;7(1):2499.

9. Zhang Y, Xue JY. Different characteristics of rabbit hair and body parts processing. Chin J Rabbit Farming. 2012;03:40-2.

10. Stenn KS, Paus R. Controls of hair follicle cycling. Physiol Rev. 2001;81(1): 449-94.

11. Tamura Y, Takata K, Eguchi A, Kataoka Y. In vivo monitoring of hair cycle stages via bioluminescence imaging of hair follicle NG2 cells. Sci Rep. 2018;8(1):393.

12. Schneider MR, Ruth SU, Ralf P. The hair follicle as a dynamic miniorgan. Curr Biol. 2009;19(3):R132-42.

13. Ding $H$, Zhao $H$, Cheng $G$, Yang $Y$, Wang $X$, Zhao $X$, et al. Analyses of histological and transcriptome differences in the skin of short-hair and longhair rabbits. BMC Genomics. 2019;20(1):140.

14. Zhao B, Chen Y, Yan X, Hao Y, Zhu J, Weng Q, et al. Gene expression profiling analysis reveals fur development in rex rabbits (Oryctolagus cuniculus). Genome. 2017;60(12):1060-7.

15. Ding $H$, Cheng $G$, Leng J, Yang $Y$, Zhao $X$, Wang $X$, et al. Analysis of histological and microRNA profiles changes in rabbit skin development. Sci Rep. 2020;10(1):454.

16. Higgins CA, Petukhova L, Harel S, Ho YY, Drill E, Shapiro L, et al. FGF5 is a crucial regulator of hair length in humans. Proc Natl Acad Sci U S A. 2014; 111(29):10648-53.

17. Kulessa H, Turk G, Hogan BL. Inhibition of bmp signaling affects growth and differentiation in the anagen hair follicle. EMBO J. 2000;19(24):6664-74.

18. Demehri $S$, Kopan R. Notch signaling in bulge stem cells is not required for selection of hair follicle fate. Development. 2009:136(6):891-6.

19. Hardy MH. The secret life of the hair follicle. Trends Genet. 1992;8(2):55-61.

20. Oro AE, Scott MP. Splitting hairs. Dissecting roles of signaling systems in epidermal development. Cell. 1998;95(5):575-8.

21. Lin CM, Yuan YP, Chen XC, Li HH, Cai BZ, Liu Y, et al. Expression of Wnt/ beta-catenin signaling, stem-cell markers and proliferating cell markers in rat whisker hair follicles. J Mol Histol. 2015;46(3):233-40.

22. Lou X, Ma X, Wang D, Li X, Sun B, Zhang T, et al. Systematic analysis of long non-coding RNA and mRNA expression changes in ApoE-deficient mice during atherosclerosis. Mol Cell Biochem. 2019;462(1-2):61-73.

23. Biao $Y$, Zhen-Hua W, Jin-Tao G. The research strategies for probing the function of long noncoding RNAs. Genomics. 2012;99(2):76-80.

24. Kornienko AE, Guenzl PM, Barlow DP, Pauler FM. Gene regulation by the act of long non-coding RNA transcription. BMC Biol. 2013;11(1):59.

25. Wang S, Ge W, Luo Z, Guo Y, Jiao B, Qu L, et al. Integrated analysis of coding genes and non-coding RNAs during hair follicle cycle of cashmere goat ( Capra hircus ). BMC Genomics. 2017;18(1):767.

26. Song S, Yang M, Li Y, Rouzi M, Zhao Q, Pu Y, et al. Genome-wide discovery of lincRNAs with spatiotemporal expression patterns in the skin of goat during the cashmere growth cycle. BMC Genomics. 2018;19(1):495.

27. Zhu YB, Wang ZY, Yin RH, Jiao Q, Zhao SJ, Cong YY, et al. A IncRNA-H19 transcript from secondary hair follicle of Liaoning cashmere goat: identification, regulatory network and expression regulated potentially by its promoter methylation. Gene. 2018;641:S0378111917308533.

28. Chang-Min L, Yang L, Keng H, Xian-Cai C, Bo-Zhi C, Hai-Hong L, et al. Long noncoding RNA expression in dermal papilla cells contributes to hairy gene regulation. Biochem Biophys Res Commun. 2014;453(3):508-14. 
29. Yue Y, Guo T, Yuan C, Liu J, Guo J, Feng R, et al. Integrated analysis of the roles of long noncoding RNA and coding RNA expression in sheep (Ovis aries) skin during initiation of secondary hair follicle. PLoS One. 2016;11(6): e0156890.

30. Chen S, Liu T, Liu Y, Dong B, Gu Z. Gene expression patterns in different wool densities of Rex rabbit using cDNA microarray. Agr Sci China. 2011; 10(4):595-601.

31. Rafat SA, Rochambeau HD, Thébault RG, David I, Deretz S, Bonnet M, et al. Divergent selection for total fleece weight in angora rabbits: correlated responses in wool characteristics. Livest Sci 2008;113(1):0-13.

32. Choi BY. Hair-growth potential of ginseng and its major metabolites: a review on its molecular mechanisms. Int J Mol Sci. 2018;19(9):2703.

33. Lin CM, Liu Y, Huang K, Chen XC, Cai BZ, Li HH, et al. Long noncoding RNA expression in dermal papilla cells contributes to hairy gene regulation. Biochem Bioph Res Co. 2014;453(3):508-14.

34. Zhao B, Chen Y, Hu S, Yang N, Wang M, Liu M, et al. Systematic analysis of non-coding RNAs involved in the angora rabbit (Oryctolagus cuniculus) hair follicle cycle by RNA sequencing. Front Genet. 2019;10:407.

35. Liu G, Li S, Liu H, Zhu Y, Bai L, Sun H, et al. The functions of ocu-miR-205 in regulating hair follicle development in Rex rabbits. BMC Dev Biol. 2020;20(1): 8.

36. Arlud S, He N, Sari EM, Ma ZJ, Zhang H, An TW, et al. Highly conserved keratin-associated protein 7-1 gene in yak, taurine and zebu cattle. Folia Biol. 2017;63(4):139-45.

37. Zhao M, Zhou H, Hickford JGH, Gong H, Wang J, Hu J, et al. Variation in the caprine keratin-associated protein 15-1 (KAP15-1) gene affects cashmere fibre diameter. Arch Anim Breed. 2019;62(1):125-33.

38. Li B, Qiao L, An L, Wang W, Liu J, Ren Y, et al. Transcriptome analysis of adipose tissues from two fat-tailed sheep breeds reveals key genes involved in fat deposition. BMC Genomics. 2018;19(1):338.

39. Clarke DL, Carruthers AM, Mustelin T, Murray LA. Matrix regulation of idiopathic pulmonary fibrosis: the role of enzymes. Fibrogenesis Tissue Repair. 2013;6(1):20.

40. Leask A. Matrix remodeling in systemic sclerosis. Semin Immunopathol. 2015;37(5):559-63.

41. Elliott K, Stephenson TJ, Messenger AG. Differences in hair follicle derma papilla volume are due to extracellular matrix volume and cell number: implications for the control of hair follicle size and androgen responses. J Invest Dermatol. 2000;113(6):873-7.

42. Chiang C, Swan RZ, Grachtchouk M, Bolinger M, Litingtung Y, Robertson EK, et al. Essential role for sonic hedgehog during hair follicle morphogenesis. Dev Biol. 1999;205(1):1-9.

43. St-Jacques B, Dassule HR, Karavanova I, Botchkarev VA, Li J, Danielian PS, et al. Sonic hedgehog signaling is essential for hair development. Curr Biol. 1998;8(19):1058-68.

44. Wang E, Harel S, Christiano AM. JAK-STAT signaling jump starts the hair cycle. J Invest Dermatol. 2016;136(11):2131-2.

45. Harel S, Higgins CA, Cerise JE, Dai Z, Chen JC, Clynes R, et al. Pharmacologic inhibition of JAK-STAT signaling promotes hair growth. Sci Adv. 2015;1(9): e1500973.

46. Liu F, Chen Y, Zhu G, Hysi PG, Wu S, Adhikari K, et al. Meta-analysis of genome-wide association studies identifies 8 novel loci involved in shape variation of human head hair. Hum Mol Genet. 2018;27(3):559-75.

47. Wu Z, Latendorf T, Meyer-Hoffert U, Schroder JM. Identification of trichohyalin-like 1, an s100 fused-type protein selectively expressed in hair follicles. J Invest Dermatol. 2011;131(8):1761-3.

48. Furstenberger G, Marks F, Krieg P. Arachidonate 8(S)-lipoxygenase. Prostaglandins Other Lipid Mediat. 2002;68-69:235-43.

49. Clements SE, Techanukul T, Lai-Cheong JE, Mee JB, South AP, Pourreyron C, et al. Mutations in AEC syndrome skin reveal a role for p63 in basement membrane adhesion, skin barrier integrity and hair follicle biology. Brit Dermatol. 2012;167(1):134-44.

50. Pertea M, Kim D, Pertea GM, Leek JT, Salzberg SL. Transcript-level expression analysis of RNA-seq experiments with HISAT. StringTie and Ballgown Nat Protoc. 2016;11(9):1650-67.

51. Young MD, Wakefield MJ, Smyth GK, Oshlack A. Gene ontology analysis for RNA-seq: accounting for selection bias. Genome Biol. 2010;11(2):R14.

\section{Publisher's Note}

Springer Nature remains neutral with regard to jurisdictional claims in published maps and institutional affiliations.

Ready to submit your research? Choose BMC and benefit from:

- fast, convenient online submission

- thorough peer review by experienced researchers in your field

- rapid publication on acceptance

- support for research data, including large and complex data types

- gold Open Access which fosters wider collaboration and increased citations

- maximum visibility for your research: over $100 \mathrm{M}$ website views per year

At BMC, research is always in progress.

Learn more biomedcentral.com/submissions 